容レ.腊驗初期ノモノニアりテハ.中耳粘膜ハ浮 隀狀ニ著シク腫脤シ，其固有結縍織層內 血管”掂张並二出血. 膿球, 浸潤顯著ナリ。日

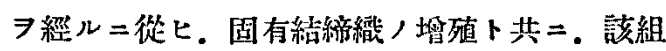
識內,骨新生現象旺ナリ。更二日フ經タルモ， 八. 粘膜組織八肉寻組織狀化シ。器質化七几膿 汁ト相接シ。其境界ヨ裁別シ得ザルモノアリ。 斯办現象八殊二上鼓室. 副室. 正並二卯圆惫

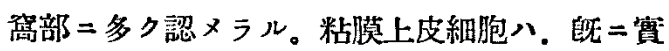
羷初期二於テ多ク破壤眖落スルモ。一般=，1 ケ月内外 $=$ 壳子形又八圆柱狀上皮 7 再成ス。 中耳腔底部，一定部位二於々儿中耳粘膜，厚サ ヨ测定比較スル二，望驗初期ノモノ二於テ八. 對照群 : 柏虂群 : 醋酸群=14:13:13 ニシテ各 動物間二著シキ差異 後 1 ケ月以上 八 7;9:12 ニシテ. 醌酸群二於ケル炎症性腫脤 最モ著シク. 對照群八最モ輕度。柑檑群八兩省 ，中間二位 $、$ 。内耳炎合併症例 7 見ル二，對照 群二於テハ化膿性症例 1 。洯液性症例 1 。林㛢 群八化縟性症例 4 。甚液性症例 2 。醋酸群二於 テ八，化愲性症例 5 獎液性症例 1 ナリ。

以上/組織學的所見ヨッ。大體二於デ，智期閒 ノ試食投與二於テ八备動物群間 =著シキ宾異 認メザレ共. 長期間二亘り. 多量，試駿食

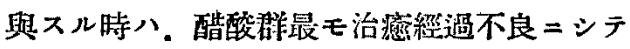
相橘群モ。䁈驗後期二八對照群二比シ劣レルラ 認ム。依ッテ是等食佴，酸監基平衡二及ボス影 響ヨ知ラント欲シ 別= 體重 $2 \mathrm{~kg}$ 內外，芜鬼 フ選ビ. 體重 $1 \mathrm{~kg}$ =付キ前記, 果汁並二酷酸

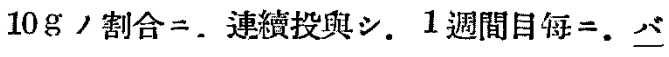
ンスライク氏法=ヨリ，血液炭酸瓦斯合有量 7 测定セシニ．1週間目二於テハ 勃レモ投其前
ニ比シ.瓦斯量 ノ低減 ア認メザレ共. 醋酸群二 アリテハ，2週間目二於テ相當，娍少ヨ認ムル モノアリ．3週間目ニハ著明ナル低減示セ リ。相橘群=於テハ，2週間目ニテハ，投與前 ニ比シ著シキ惹フ認メザルノミナラズ. 却ツテ 益々瓦斯量,增加习示スモノアリ。然レ共。一

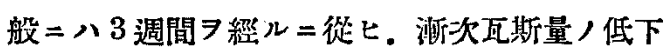

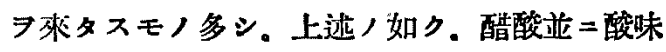
高度ナル相楺類，投㠘=因り「アチドージス」 或ハ「アチドージス」㑡二移行スル事习認ムル ヨ以テ.之二因ル生活力八低下ガ. 前記/如キ 結果 招來セルモノト思惟ス。

\section{4. 腦水腫㯖器標本供覽}

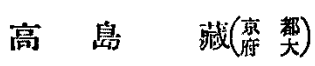

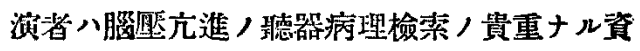

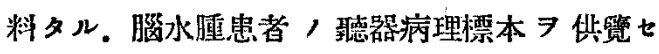
リ。患者八生後 5 ケ月ノ男兒ニシテ外㨫水腫. 涫化不良症ナル診斷名，下=死亡．剖检二附七 ラレタルモノナリ。患兒ノ頭圍八侍大小兒科. 中村恒男學士ノ計测 $=ヨ$ レバ $73 \mathrm{~cm}$ ，大サヨ示 シ. 成人頭大以上/巨大ナル頭藍

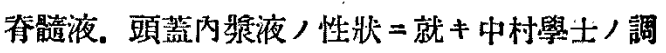
查成績 7 紹介シタル後. 竍㗊病理=就キ下記，

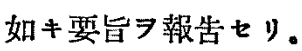

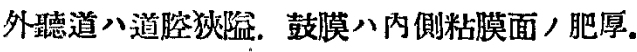
充血. 圆形細胞浸潤7認メ.中耳八化膿。同骨

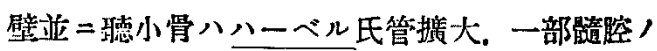
繊維化 7 證明

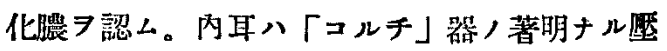
平萎縮.「ライスネル膜八消失乃至變形シ. 蠌

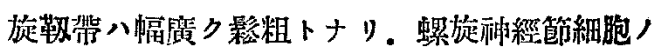
變性乃至消失 7 見ル。「ローゼンタール管八綃 締織ニテ充タサレ，或八骨質ノ㫮殖ヨ示シ.内 


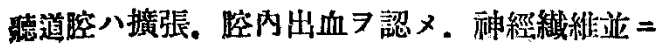
スカルパ氏神經篩細胞，變性乃至消失 7 見ル。

\section{5. 結榕性中耳炎二合併飞ルS 字狀}

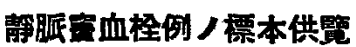

高 橋良(節 雬)

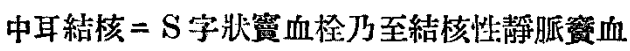
栓 フルノ゙ナリ。余八最近之等/ 4 例 5 耳二粪遇 セシ故報告スルモノナリ。

第 1 例. 15 歲男子. 肋膜炎睢患後 1 年ニシテ 兩側中耳結核习來タシ右耳八根治手術习施行七 シモ耳發病後 4 ケ月ニシテ死亡セシモノニシテ 剖檢所見八全身柔粒結核ニシテ畺器八左側八一 般二强ク渗出性二侵サレ筧骨壁ハ一部缺損シ赛 壁八結㤥性浸潤 7 受々中二約 $5 \mathrm{~cm}$ 大ノ凝血血栓 ヨ認ムルモ血栓二結核性病變八認メザリキ。右 側へ左側ヨリ强ク侵サレ滲出性病變强ク筼骨壁 八强ク破壞サレ空壁及ビ內膑二乾酪變性 ル血栓フ認メタリ。

第 2 例。7 歲男子。助膜炎羅患後一般，靜哌

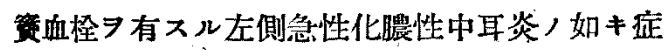
彇ニテ發病シ之二血栓ノ手術 不良ニシテ結核性腦膜炎ニテ死亡セリ。之が剖 检所見八肺及ビ聼器共渗出增殖性ニシテ S 字狀 等壁及ビ内腔八乾酪變性 7 廣沉ニ示シタリ。

第 3 例。9 月月男子. 麻疹後丽側絬核性中耳 炎 称病シ之ガ 2 ケ月牛ニテ死亡セシモノニシ テ. 剖检所見八肺描器共高度ナ儿滲出性結核二

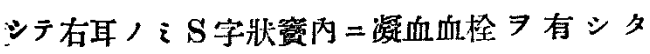
1)

第 4 例。7 啙男子。昁門淋巴腺腄㭽ノ診斷了 リシ後急性中耳炎习來タシ之が 20 日二シテ死 亡セルモノシシテ．剖檢所見八全身絬核。結核

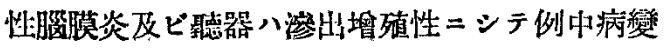
八最モ輕度ナリ。

即チ以上ヨリ 2 耳八確實二結核性靜脈察血栓デ アリ 2 耳ハ中耳結核二伴へル凝血血栓ニシテ殘 ル 1 耳心凝血血栓ナリシカ死後凝血ナリシカ制 斷二苦シムモノナリ。

之等，靜胍䇱血栓二就テハ其症狀八幼小兒ナリ シタメト肺結核ノタメ不定デアッテ診斷八甚ダ 困慕 7 感ジタルモ文㱆二於テモ同樣ナリキ。倘

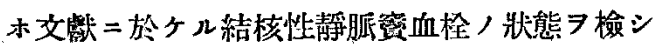
マスル $=4$ 種 7 認ムベシ。郎チ第一二嘪壁二變 化アリテ凝血血栓习入ル、モ，第二゙二內腔消 失シ癒着スルモ，。第三二乾酷塊 第四二璂壁肉芽性ニシテ出血性ノモノニシテ余 ，症例ニテハ之等/中 2 種 7 認メタルナリ。

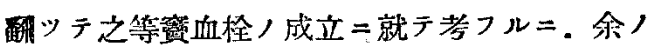
得タル症例ヨリ考フレバ. 幼小兒ノ抵抗力少キ 時期二起り易っ全身並二局所機轉二於テハ滲出 性乃至渗出增殖性機轉二起り易キモ，、如～ 又第 2 例二明カ二若一得ラル、如ク、Cemach ，謂へル如ク混合感染が與ツテカナキヤ. 刃第 1 例. 第 2 例 $=$ 見ラル、如ク手街八病變强キ結

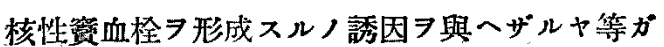
考へ得ラル、モノナリ。(近り原著トシラ發表ス ベシ)。

\section{6. 乳嘴蜂巢內二發生セ儿黃色腫症例}

$$
\text { 金子計三(蓝 檠) }
$$

橫色腫八近時真性腫瘍二非ズシテ絧狀織內被

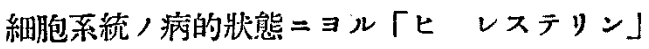
質沈着症卜解七ラル、二到ツタノデァル。私ハ

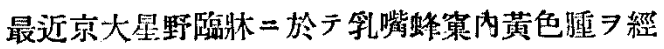
驗シタノデ弦二報告ス。患者ハ 20 歳/男子. 5 ケ月前カラ右側耳漏がアル。遺傅關係. 皮属其 